Review

\title{
Predicting the Response of Neoadjuvant Therapy for Patients with Esophageal Carcinoma: an In-depth Literature Review
}

\author{
Chang-Juan Tao ${ }^{*}$, Gang $\operatorname{Lin}^{1^{*}}$, Ya-Ping Xu1 ${ }^{\bowtie}$, Wei-Min Mao ${ }^{2 \bowtie}$ \\ 1. Department of Radiation Oncology, Zhejiang Cancer Hospital, No. 38 Guangji Rd., Hangzhou, Zhejiang, 310022, China \\ 2. Department of Thoracic Surgery, Zhejiang Cancer Hospital, No. 38 Guangji Rd., Hangzhou, Zhejiang, 310022, China \\ ${ }^{*}$ Chang-Juan Tao and Gang Lin contributed equally to this manuscript.
}

$\triangle$ Corresponding authors: Ya-Ping Xu M.D., Department of Radiation Oncology, Zhejiang Cancer Hospital, No. 38 Guangji Rd., Hangzhou, Zhejiang, 310022, China. Tel.: 86-571-88128168; Fax: 86-571-88128168; E-mail: xuyaping1207@163.com; Wei-Min Mao M.D., Department of Thoracic Surgery, Zhejiang Cancer Hospital, Zhejiang Key Laboratory of the Diagnosis \& Treatment Technology on Thoracic Oncology, No. 38 Guangji Rd., Hangzhou, Zhejiang, 310022, China. Tel.: 86-571-88122388; Fax: 86-571-88122388; E-mail: maowmzj1218@163.com

() 2015 Ivyspring International Publisher. Reproduction is permitted for personal, noncommercial use, provided that the article is in whole, unmodified, and properly cited. See http:/ /ivyspring.com/terms for terms and conditions.

Received: 2015.04.08; Accepted: 2015.06.12; Published: 2015.09.15

\begin{abstract}
Currently, the most promising strategy to improve the prognosis of advanced esophageal cancer is neoadjuvant chemoradiation (CRT) followed by surgery. However, patients who achieved pathological complete response can experience more survival benefit. Therefore, it is critical to identify the responders early in the course of treatment. Published data demonstrate that clinic-histopathological factors, molecular biomarkers, and functional imaging are predictive of neoadjuvant therapy. The existing biomarkers, including epidermal growth factor receptors, angiogenetic factors, transcription factors, tumor suppressor genes, cell cycle regulators, nucleotide excision repair pathway, cytokines, and chemotherapy associated genes, need to be validated and novel biomarkers warrant further exploration. Positron emission tomography (PET) is useful for differentiating the responders of neoadjuvant CRT. The most valuable parameters and the time point of performing PET in the course of treatment remains to be elucidated. Furthermore, predictive models incorporating the multiple categories of factors need to be established with a large, prospective, and homogeneous patient cohort in the future. Standardization of staging, biomarker detection method, and image acquisition protocol will be critical for the generalization of this model. Prospective, multi-center controlled trials, which stratified patients according to these predictive factors, will help guide individualized treatment strategies for patients with esophageal cancer.
\end{abstract}

Key words: esophageal cancer, neoadjuvant therapy, response, positron emission tomography, biomarkers

\section{Introduction}

According to the International Agency for Research on Cancer, there were an estimated 482,000 incident cases of esophageal cancer (EC) with high mortality (84\%) around the world in 2008 [1]. EC often infiltrates neighboring organs and easily metastasizes to lymph nodes, and as a result, the prognosis of locally advanced patients is extremely poor, with a 5 -year survival of $15-34 \%$ [2]. One possible way to further improve the prognosis of EC is multimodal comprehensive treatment. More recently, preoperative chemoradiotherapy (CRT) has gained popularity with physicians, as its tolerance is better than postoperative CRT, permits downstaging and higher respectability in the subsequent surgery, and may eradicate occult distant disease. Several randomized clinical trials have testified a significant survival ben- 
efit for neoadjuvant CRT in patients with squamous-cell carcinoma or adenocarcinoma of the esophagus [2-4]. Sjoquist et al. [5] recently conducted a meta-analysis, which included 24 clinical trials and 4188 patients with resectable esophageal carcinoma. The results showed that neoadjuvant CRT provided an $8.7 \%$ absolute survival benefit at 2 years after surgery alone and $5.1 \%$ survival benefit after neoadjuvant chemotherapy. Unfortunately, not all esophageal cancer patients benefit from neoadjuvant CRT. A proportion of patients show minor or no response to CRT and are merely exposed to its toxicity. Furthermore, neoadjuvant treatment produces a pathological complete response, and outcomes are better [6]. One retrospective study from Stahl et al. [7] showed that the overall survival was significantly hampered in patients with residual tumor in their resected specimen compared with patients who showed a pathological complete tumor remission (overall survival rate at 3 years $25.2 \%$ versus $65.6 \%$; hazard ratio [HR] $=$ $3.50 ; 95 \%$ confidence interval [CI] 1.91-6.44; $\mathrm{p}<$ $0.0001)$.

The treatment of tumors has currently stepped into an individualized era. It is vital to select patients who will experience survival benefit from receiving neoadjuvant CRT before treatment. Furthermore, several studies have reported that surgery can be omitted in patients that achieved pathological complete response (pCR) after neoadjuvant CRT [8, 9]. In this article, we summarize the recent literature with respect to the predictive factors of neoadjuvant CRT response and provide a review the progress of the field and future challenges to be expected.

\section{Clinical and histopathological factors}

Predictive biomarkers and functional imaging have become a hot technique for the individualized treatment of cancer. However, traditional clinical factors, such as tumor stage, patient age, and performance status, are still used to select the best therapy for a particular patient. Szumilo et al. [10] initially found that tumor invasion depth was the only clinical factor significantly correlated with response to preoperative chemotherapy for thoracic esophageal squamous cell carcinoma (ESCC). Huang et al. [11] and Hamai et al. [12] identified that age, baseline hemoglobin level, smoking habit, and tumor length were important $\mathrm{pCR}$ predictors in ESCC. In patients with esophageal adenocarcinoma, Patel et al. [13] found that signet ring cell histology on pretreatment biopsy predicts a decreased likelihood of $\mathrm{pCR}$ and survival. Additionally, prediction model or nomogram has greatly increased in the past several years. Schneider et al. [14] created a regression classification based on two parameters (histomorphologic tumor regression and postoperative pathological node stage) to predict the complete resections following neoadjuvant CRT for EC patients. Additionally, Ajani et al. [15] established a nomogram to predict the pCR of this protocol. The following parameters were incorporated into this model: post-chemoradiation positron emission tomography (PET) standardized unit value (SUV), post-chemoradiation biopsy, sex, histologic tumor grade, and baseline endoscopic ultrasonography tumor stage. The area under the receiver-operating characteristic curve was 0.72 (95\% CI: $0.662-0.787)$. This model needs to be prospectively validated before it can be used in clinical practice.

Serum C-reactive protein (CRP) as an inflammatory factor has also been evaluated in the treatment response prediction of EC patients. Fujiwara et al. [16] was the first to demonstrate that serum CRP levels during CRT were closely associated with the pathological response, particularly in patients with elevated CRP prior to CRT, a decrease in CRP within normal ranges 2-3 weeks following CRT initiation predicted a favorable pathological response with the highest accuracy.

\section{Biomarkers}

A large spectrum of biomarkers at the level of alterations of genomic DNA, gene expression of messenger RNA (mRNA), micro-RNA (miRNA), and protein expression have been identified and analyzed to predict the response of neoadjuvant therapy.

Cisplatin (CDDP) and 5-fluorourcil (5-FU) based neoadjuvant chemotherapy have been widely used in clinical practice. The excision repair cross-complementing 1 (ERCC1) gene codes for a nucleotide excision repair protein involved in the repair of radiation- and chemotherapy-induced DNA damage. Warnecke et al. [17] and Metzger et al. [18] testified that ERCC1 mRNA expression and ERCC1 (rs11615) gene polymorphisms correlated with treatment response to CDDP-based chemotherapy. Furthermore, RNA expression levels of 5-FU metabolism-associated genes, thymidylate synthase (TS), dihydropyrimidine dehydrogenase (DPD), thymidine phosphorylase (TP), methylenetetrahydrofolate reductase (MTHFR), as well as of CDDP and taxane-related genes gluthatione S-transferase (GSTP-1), Caldesmon, and multi-drug resistance gene (MRP1) have been testified to be predictors of response to neoadjuvant therapy [19-22].

MiRNAs are small noncoding RNAs, which are involved in the regulation of gene expression by inhibiting messenger RNA translation [23]. A few studies have investigated its predictive role for therapeutic response. Odenthal et al. [24] conducted a comprehensive miRNA profiling in 16 specimens 
with pre-neoadjuvant and post-neoadjuvant therapy, and the selected miRNAs were verified in 80 EC patients. The results showed that miR-192 and miR-194 in pre-therapeutic biopsies are considered indicators of major histopathologic regression. Moreover, in vitro assays showed that miR-296 and miR-200c expression correlated with chemotherapy resistance [25, 26]. Furthermore, miR-148a has been reported to improve response to chemotherapy in sensitive and resistant esophageal carcinoma cells [27].

Long non-coding RNAs (LncRNAs) are a new class of non-protein-coding RNAs, which are longer than 200 bases [28]. Tong et al. [29] initially explored the relationship between LncRNA LOC285194 and the response to neoadjuvant CRT in ESCC and showed that the decreased expression of LOC285194 indicated CRT resistance and poor prognosis. Other biomarkers, such as epidermal growth factor receptor (EGFR), vascular endothelial growth factor (VEGF), proliferating cell nuclear antigen (PCNA), p53 status, p21 status, Bcl-2, Ki-67, transcription factor nuclear factor $\mathrm{kB}(\mathrm{NF}-\mathrm{kB})$, and Rad51 have been shown to correlate with response to neoadjuvant therapy in EC [30-39] (Table 1).

Table 1. Studies demonstrating the potential of molecular biomarkers to predict histopathological response to neoadjuvant therapy in esophageal cancer.

\begin{tabular}{|c|c|c|c|c|c|c|c|}
\hline Study & Cancer & $\begin{array}{l}\text { Neoad- } \\
\text { juvant } \\
\text { treatment }\end{array}$ & $\begin{array}{l}\text { Sample } \\
\text { size }\end{array}$ & Method & specimen & predictive factor & $\begin{array}{l}\text { Type of cellular } \\
\text { pathway/factor }\end{array}$ \\
\hline $\begin{array}{l}\text { Hickey et } \\
\text { al.(1994) [31] }\end{array}$ & SCC & CRT & 14 & IHC & $\begin{array}{l}\text { Pretreatment } \\
\text { biopsy }\end{array}$ & $\begin{array}{l}\text { EGFR or PCNA negative indicates } \\
\text { response to CRT }\end{array}$ & $\begin{array}{l}\text { Growth factor receptors } \\
\text { Cell proliferation }\end{array}$ \\
\hline $\begin{array}{l}\text { Sarbia et al. } \\
(1998)[32]\end{array}$ & SCC & CRT & 38 & IHC & $\begin{array}{l}\text { Pretreatment } \\
\text { biopsy }\end{array}$ & $\begin{array}{l}\text { P53 negative and } \\
\text { week Bcl-2 related X protein expres- } \\
\text { sion are positive predictors }\end{array}$ & $\begin{array}{l}\text { Tumour suppressor } \\
\text { Genes and apoptosis }\end{array}$ \\
\hline $\begin{array}{l}\text { Nakashima et } \\
\text { al.(2000) } \\
{[33]}\end{array}$ & SCC & $\begin{array}{l}\text { chemo- } \\
\text { therapy }\end{array}$ & 30 & IHC & $\begin{array}{l}\text { Pretreatment } \\
\text { biopsy }\end{array}$ & $\begin{array}{l}\mathrm{P} 53 \text { negative and } \mathrm{P} 21 \text { positive indi- } \\
\text { cates response to chemo }\end{array}$ & $\begin{array}{l}\text { Tumour suppressor } \\
\text { Genes and Cell cycle regulators }\end{array}$ \\
\hline $\begin{array}{l}\text { Kitamura et } \\
\text { al. (2000) [34] }\end{array}$ & $\mathrm{EC}$ & CRT & 95 & $\mathrm{IHC}$ & Biopsy tissue & $\begin{array}{l}\text { P53 negative and } \mathrm{Ki}-67 \text { antigen posi- } \\
\text { tive indicates response to CRT }\end{array}$ & $\begin{array}{l}\text { Tumour suppressor } \\
\text { Genes and cell proliferation }\end{array}$ \\
\hline $\begin{array}{l}\text { Miyazono et } \\
\text { al.(2004) } \\
\text { [35] }\end{array}$ & $\begin{array}{l}\text { SCC: } 63.9 \% \\
\text { AC: } 36.1 \%\end{array}$ & CRT & 36 & $\begin{array}{l}\text { qRT-PCR } \\
\text { assay }\end{array}$ & $\begin{array}{l}\text { Pretreatment } \\
\text { biopsy }\end{array}$ & $\begin{array}{l}\text { c-erB- } 2 \text { mRNA expression is a nega- } \\
\text { tive marker of response prediction }\end{array}$ & DNA damage repairing \\
\hline $\begin{array}{l}\text { Warnecke et } \\
\text { al.(2004) [17] }\end{array}$ & $\begin{array}{l}\text { SCC: } 63.9 \% \\
\text { AC: } 36.1 \%\end{array}$ & CRT & 36 & qRT-PCR & $\begin{array}{l}\text { Pretreatment } \\
\text { biopsy }\end{array}$ & $\begin{array}{l}\text { ERCC1 mRNA expression level } \\
\text { correlated with minor response to } \\
\text { cisplatin based neo-CRT }\end{array}$ & $\begin{array}{l}\text { Nucleotide excision } \\
\text { repair pathway }\end{array}$ \\
\hline $\begin{array}{l}\text { Izzo et al. } \\
(2006)[36]\end{array}$ & $\begin{array}{l}\text { SCC: } 2 \% \\
\text { AC: } 98 \%\end{array}$ & CRT & 43 & IHC & $\begin{array}{l}\text { Pre-and } \\
\text { post-treatment } \\
\text { biopsy }\end{array}$ & NF-kB promotes CRT resistance & Transcription factors \\
\hline $\begin{array}{l}\text { Tong et al. } \\
\text { (2014) [29] }\end{array}$ & SCC & CRT & 142 & qRT-PCR & $\begin{array}{l}\text { Pretreatment } \\
\text { biopsy }\end{array}$ & $\begin{array}{l}\text { Decreased lncRNA LOC285194 sug- } \\
\text { gested CRT resistance }\end{array}$ & $\begin{array}{l}\text { Regulate the expression of prolif- } \\
\text { eration-associated genes }\end{array}$ \\
\hline $\begin{array}{l}\text { Ajani et al. } \\
(2014)[39]\end{array}$ & $\begin{array}{l}\text { SCC: } 4.19 \% \\
\text { AC: } 95.81 \%\end{array}$ & CRT & 167 & IHC & $\begin{array}{l}\text { Pretreatment } \\
\text { biopsy }\end{array}$ & $\begin{array}{l}\text { High expression of } \\
\text { ALDH-1suggested CRT resistance }\end{array}$ & $\begin{array}{l}\text { Cancer stem cell (CSC) markers } \\
\text { which capable of repopulation } \\
\text { of resistant }\end{array}$ \\
\hline $\begin{array}{l}\text { Warnecke et } \\
\text { al. (2010) [20] }\end{array}$ & EC & CRT & 41 & $\begin{array}{l}\text { Low-densit } \\
\text { y-array } \\
\text { RT-PCR }\end{array}$ & $\begin{array}{l}\text { Pretreatment } \\
\text { biopsy }\end{array}$ & DPD indicates major response & $\begin{array}{l}\text { Chemotherapy } \\
\text { associated genes }\end{array}$ \\
\hline $\begin{array}{l}\text { Metzger et al. } \\
(2012)[18]\end{array}$ & $\mathrm{AC}$ & CRT & 217 & qRT-PCR & $\begin{array}{l}\text { Paraffin-embedded } \\
\text { tissues from resec- } \\
\text { tion }\end{array}$ & $\begin{array}{l}\text { ERCC1 (rs11615) gene polymor- } \\
\text { phisms }\end{array}$ & $\begin{array}{l}\text { Nucleotide excision } \\
\text { repair pathway }\end{array}$ \\
\hline $\begin{array}{l}\text { Cheng et al. } \\
\text { (2014) [30] }\end{array}$ & SCC & CRT & 79 & $\begin{array}{l}\text { PLA } \\
\text { ELISA }\end{array}$ & $\begin{array}{l}\text { Serum before and } \\
<1 \text { month after } \\
\text { CCRT }\end{array}$ & $\begin{array}{l}\text { Low VEGF-A levels indicates re- } \\
\text { sponse to neo-CRT }\end{array}$ & Giogenetic factors \\
\hline $\begin{array}{l}\text { Odenthal et } \\
\text { al. (2012) [24] }\end{array}$ & $\begin{array}{l}\text { SCC: } 48 \% \\
\text { AC: } 52 \%\end{array}$ & CRT & 88 & $\begin{array}{l}\text { miRNA } \\
\text { profiling } \\
\text { and } \\
\text { RT-PCR }\end{array}$ & $\begin{array}{l}\text { Pre-and } \\
\text { post-treatment } \\
\text { biopsy }\end{array}$ & $\begin{array}{l}\text { miR-192 and miR-194 are considered } \\
\text { as indicators of major respomse }\end{array}$ & $\begin{array}{l}\text { miR-192: 5-FU metabolism; } \\
\text { miR-194 targets the suppressor of } \\
\text { cytokine signaling } 2\end{array}$ \\
\hline $\begin{array}{l}\text { Hofler et al. } \\
\text { (2006) [19] }\end{array}$ & $\mathrm{AC}$ & $\begin{array}{l}\text { chemo- } \\
\text { therapy }\end{array}$ & 38 & RT-PCR & $\begin{array}{l}\text { Pretreatment } \\
\text { biopsy }\end{array}$ & $\begin{array}{l}\text { MTHFR } \\
\text { Caldesmon } \\
\text { MRP1 and MDR1 }\end{array}$ & $\begin{array}{l}\text { Chemotherapy } \\
\text { associated genes }\end{array}$ \\
\hline $\begin{array}{l}\text { Theisen et al. } \\
\text { (2008) [21] }\end{array}$ & $\mathrm{AC}$ & $\begin{array}{l}\text { chemo- } \\
\text { therapy }\end{array}$ & 32 & RT-PCR & $\begin{array}{l}\text { Pretreatment } \\
\text { biopsy }\end{array}$ & $\begin{array}{l}\text { Low expression of TS, ERCC } 1 \text { and } \\
\text { GSTP- } 1 \text { mRNA indicates good re- } \\
\text { sponse }\end{array}$ & $\begin{array}{l}\text { Chemotherapy } \\
\text { associated genes }\end{array}$ \\
\hline $\begin{array}{l}\text { Nakanoko et } \\
\text { al. (2014) [37] }\end{array}$ & SCC & CRT & 39 & IHC & $\begin{array}{l}\text { Pretreatment } \\
\text { biopsy }\end{array}$ & Rad51-negative indicates pCR & Homologous recombination \\
\hline $\begin{array}{l}\text { Brabender et } \\
\text { al. (2012) [22] }\end{array}$ & $\begin{array}{l}\text { SCC: } 10 \\
\text { AC: } 19\end{array}$ & CRT & 29 & RT-PCR & blood & $\begin{array}{l}\text { High expression of TS RNA indicates } \\
\text { minor response }\end{array}$ & $\begin{array}{l}\text { Chemotherapy } \\
\text { associated genes }\end{array}$ \\
\hline
\end{tabular}




\begin{tabular}{|c|c|c|c|c|c|c|c|}
\hline $\begin{array}{l}\text { Zhou et al. } \\
\text { (2011) [38] }\end{array}$ & SCC & $\begin{array}{l}\text { CRT or } \\
\text { chemo- } \\
\text { therapy }\end{array}$ & 230 & RT-PCR & $\begin{array}{l}\text { Pretreatment } \\
\text { biopsy }\end{array}$ & $\begin{array}{l}\text { TGF- } \beta 1-509 \mathrm{C} / \mathrm{T} \text { polymorphisms } \\
\text { were associated with response to } \\
\text { pre-CRT }\end{array}$ & Transforming growth factor \\
\hline $\begin{array}{l}\text { Makuuchi et } \\
\text { al.[41] }\end{array}$ & SCC & CRT & 37 & $\begin{array}{l}\text { serum } \\
\text { profile }\end{array}$ & serum & $\begin{array}{l}\text { Increased sIL6R correlated with poor } \\
\text { response to pre-CRT. }\end{array}$ & Host immune \\
\hline
\end{tabular}

Abbreviations: CRT, chemoradiotherapy; EGFR, epidermal growth factor receptor; PCNA: proliferating cell nuclear antigen; ERCC1, excision crosscomplementing gene 1; c-erB-2, human epidermal growth factor receptor-2; VEGF, vascular endothelial growth factor; IncRNA, long noncoding RNA; IHC, immunohistochemistry; ALDH-1: aldehyde dehydrogenase-1; sIL6R: serum soluble interleukin-6 receptor; DPD: Dihydropyrimidine dehydrogenase; MRP1 and MDR1, multidrugresistance protein 1; MTHFR, methylenetetrahydrofolate reductase; TS, thymidylate synthase.; GSTP-1, gluthatione S-transferase; NF-kB, nuclear factor-kB; TGF- $\beta 1$, transforming growth factor- $\beta 1$; pCR, pathological complete response; qRT-PCR, quantitative real-time polymerase chain reaction; ESCC, esophageal squamous cell carcinoma; EAC: esophageal adenocarcinoma caicinoma; CRT: chemoradiotherapy;

The above mentioned biomarkers were examined using a biopsy specimen. Noninvasive molecular markers may be more applicable and promotable in the clinic. Cheng et al. [30] adopted the proximity ligation assay (PLA) followed by enzyme-linked immunosorbent assay (ELISA) to identify serum biomarkers that predict treatment response of neoadjuvant CRT in 79 ESCC patients. Both methods testified that low pretreatment serum vascular endothelial growth factor-A (VEGF-A) significantly correlated with $\mathrm{pCR}$. However, the predictive value of transforming growth factor (TGF)- $\beta 1$ was not validated by ELISA. Brabender et al. [22] also revealed that TS and DPD RNA expression in the peripheral blood of EC patients could be highly specific predictors to identify a subset of patients who do not benefit from neoadjuvant chemoradiotherapy.

It has been reported that chemoradiotherapy induces cancer cell death through tumor antigen-specific T cell response [40]. Thus, host immune status might influence the efficacy of chemoradiotherapy. Makuuchi et al. [41] conducted serum profiling of 84 cytokines in ESCC patients who received neoadjuvant CRT plus surgery and revealed that increased serum soluble interleukin- 6 receptor was correlated with a poor response to preoperative therapy.

\section{Whole genome gene expression array}

It is recognized that multiple gene alterations are involved in the development and progression of EC [42]. Markers originating from different molecular levels, such as gene expression, mRNA expression, protein expression, epigenetic modification, and mutation, have always been validated independently in separate studies. Given that tumor cells interact at different levels in the organism, which interferes with angiogenesis, DNA repair and apoptosis, cell cycle control pathways, or cell-to-cell communication pathways, analysis of one pathway alone cannot cope with the complexity of the interacting tumor cells. Whole genome microarray technology allows for high-throughput identification of gene expression profiles in cancers [43]. This approach had already been used to identify genes that could serve as bi- omarkers of neoadjuvant CRT response prediction. Table 2 summarizes the whole genome profile-related studies regarding the neoadjuvant CRT response prediction.

Luthra et al. [44] initially identified a combination of three differentially expressed genes (PERP, S100A2, and SPRR3) that allowed for the discrimination between $\mathrm{pCR}$ and $<\mathrm{pCR}$ with sensitivity and specificity of $85 \%$ after profiling pretreatment cancer biopsies from 19 EC patients that received neoadjuvant CRT. Duong et al. [45] performed cDNA microarrays of 46 pretreatment endoscopic biopsy samples and identified a 32-gene classifier that can be used to predict the response to CRT in ESCC. Motoori et al. [46] performed gene expression profiling on pretreatment samples of ESCC patients who received chemotherapy, and constructed a diagnostic system with 199 most informative genes that showed 82\% accuracy. Schauer et al. [47] proved that the Ephrin B3 receptor, a differentially expressed gene via microarray, is related to the neoadjuvant chemotherapy response. Metzger et al. [48] identified two novel markers, CUL2 and STK11 using human genome microarrays, for response prediction in EC. Mahar et al. [49] established a five gene based model that predicted the response to neoadjuvant CRT with 95\% accuracy in $74 \%$ of EC patients. Wen et al. [50] also performed gene expression profiling on pretreatment biopsies from 28 ESCCs who received neoadjuvant CRT in a phase III clinical trial and developed a prediction model based on three genes (MMP, LIMCH1, Clorf226) with $81 \%$ accuracy in the validation cohort (Table 2).

When interpreting these findings, attention must be paid to several points. First, most markers presented within this review were mainly generated by focusing on relatively small cohorts within retrospective analyses. The results are mostly preliminary and require further validation. For popularization and application of these biomarkers, large prospective trials are warranted. Second, the methods of analysis should be standardized and simplified further. Methods applied in research have to be adapted to be clinically applicable. Third, the pretreatment staging of the disease must be accurate. The staging is an 
important prognostic factor for EC, which affects statistical analysis. Finally, the CRT or chemotherapy response must be evaluated pathologically. Conventional imaging modalities (endoscopy, endoscopic ultrasonography, computed tomography, and magnetic resonance imaging) cannot reliably differentiate between viable tumor and inflammatory reactions, edema, and scar tissue [51, 52].

\section{Functional imaging data}

Positron-emission-tomography with the glucose analog fluorodeoxyglucose (FDG-PET) is a functional imaging modality that can detect changes in tissue metabolism. Current evidence has shown that tumor metabolic activity has been proven to correlate with histopathologic response in EC [53]. However, PET-based parameters to stratify prognosis in the literature has varied from different studies, including pre-radiation standard unit value (SUV), post-radiation SUV, a percentage decrease of SUV, PET-tumor length, and PET-tumor volume based parameters.

The pretreatment PET evaluation is quite important in developing a strategy to identify the value of therapy in its early stage. Kato et al. [54] showed that pretreatment SUV is a reliable predictor of response to definitive CRT in ESCC. Javeri et al. [55] also demonstrated that an initial SUV higher than the median (10.1) was associated with a better pathologic response.

More attention has been paid to the dynamic changes of SUV and the timing of post-radiation FDG-PET imaging. Several studies testified that the decrease of SUV post-neoadjuvant therapy or preoperatively can be useful for predicting pathologic response [58-61]. However, Swisher et al. [56] found that post-CRT SUV was predictive of pathologic response with a relatively low specificity. This high false positive rate may be due to the inflammatory changes following radiotherapy, which leads to falsely elevated SUV values because of the presence of metabolically active leukocytes and macrophages. Therefore, the timing of rechecking FDG-PET in the course of therapy may be critical because the false positive rate appears to decrease with time [57]. To address this question, Wieder et al. [58] studied the time course of changes in tumor FDG-uptake in patients with ESCC patients treated with preoperative therapy. The results showed that metabolic changes within the first 2 weeks of therapy are slightly better predictors compared with later changes. This observation is most likely related to the complex proinflammatory and anti-inflammatory effects of radiation, which are strongly dependent on time and dose. The authors conceived that the cytotoxic effects of radiotherapy on radiosensitive cells, such as lymphocytes, limit the intensity of inflammatory reactions in the tumor tissue during and early after completion of therapy. Additionally, in consideration of the application of SUV in clinical practice, relative changes are better predictors of CRT response than absolute SUVs, as absolute SUVs are much more sensitive to differences in data acquisition, image reconstruction, and data analysis than relative changes [59].

Except for the SUV value, other PET image-derived parameters, such as tumor longitudinal length (TL) and volume (TV) and total lesion glycolysis $(\mathrm{TLG}=\mathrm{TV} \times \mathrm{SUV}$ mean), had also been evaluated in the therapy response prediction. Hatt et al. [62] investigated the predictive value of baseline FDG-PET image-derived parameters regarding therapy response in EC patients. For study purposes, the tumor was automatically delineated on the baseline PET image using an adaptive threshold and the automatic fuzzy locally adaptive Bayesian (FLAB) methodologies to attract the TL, TV, SUV, and the derived TLG values. The results showed that commonly used parameters, such as SUVs, were not significant predictive factors of the response; parameters related to tumor functional spatial extent (TL, TV, TLG) could significantly differentiate histological response with sensitivity above $75 \%$ and specificity above $85 \%$, regardless of the functional volume delineation strategy. However, these results cannot be repeated by Blom et al. [63], who revealed that baseline MTV and TLG were not found to be predictors of response to neoadjuvant therapy in EC patients, although a trend towards a correlation between response to CRT and smaller MTV was observed. This discrepancy may be related to the limited accuracy and reproducibility of the available tumor delineation methods, small sample size, and different response evaluation criteria in both studies.

More recently, the spatial-temporal FDG-PET has gained popularity with physicians, which offers more information, including intensity features, texture features (spatial patterns), geometry features, and geometry-intensity features (total glycolytic volume), compared to the conventional PET measures with SUV [64]. Zhang et al. [65] initially built a predictive model using multiple, comprehensive tumor response measures, including conventional FDG-PET measures, clinical parameters, and demographics, and spatial-temporal FDG-PET features. This model achieved very high accuracy $(100 \%$ sensitivity and $100 \%$ specificity) for prediction of pathologic tumor response to CRT in 20 patients with EC. This model needs to be validated with a large and prospective patient cohort. 
Table 2. Studies regarding the potential biomarkers of neoadjuvant-CRT response prediction using whole-genome gene expression array in esophageal cancer.

\begin{tabular}{|c|c|c|c|c|c|c|}
\hline Investigator & cancer & $\begin{array}{l}\text { Neoadjuvant } \\
\text { treatment }\end{array}$ & $\begin{array}{l}\text { No. of } \\
\text { patients }\end{array}$ & method & specimen & predictive factor \\
\hline $\begin{array}{l}\text { Metzger et } \\
\text { al.(2010) [48] }\end{array}$ & $\begin{array}{l}\text { SCC: } 61 \% \\
\text { AC: } 39 \%\end{array}$ & CRT & 66 & $\begin{array}{l}\text { whole-genome gene-expression } \\
\text { array and qRT-PCR }\end{array}$ & $\begin{array}{l}\text { Pretreatment } \\
\text { biopsy }\end{array}$ & $\begin{array}{l}\text { Downregulation of CUL2 and STK11 mRNA } \\
\text { expression indicates minor response }\end{array}$ \\
\hline $\begin{array}{l}\text { Motoori et al. } \\
(2010)[46]\end{array}$ & $\begin{array}{l}\text { ESCC } \\
\text { training cohort: } 25 \\
\text { validation cohort }: 10\end{array}$ & CRT & 35 & $\begin{array}{l}\text { whole-genome gene-expression } \\
\text { array and qRT-PCR }\end{array}$ & $\begin{array}{l}\text { Pretreatment } \\
\text { biopsy }\end{array}$ & $\begin{array}{l}\text { A diagnostic system was established with } \\
199 \text { genes and showed } 82 \% \text { of accuracy }\end{array}$ \\
\hline $\begin{array}{l}\text { Luthra et al. } \\
\text { (2005) [44] }\end{array}$ & $\begin{array}{l}\text { AC: } 16 / 19 \\
\text { SCC: } 2 / 19 \\
\text { ASCC }: 1 / 19\end{array}$ & CRT & 19 & $\begin{array}{l}\text { oligonucleotide microarrays and } \\
\text { qPCR }\end{array}$ & $\begin{array}{l}\text { Pretreatment } \\
\text { biopsy }\end{array}$ & $\begin{array}{l}\text { Using a combination marker approach, } \\
\text { levels of PERP, S100A2, and SPRR3 allowed } \\
\text { discrimination of pCR with high } \\
\text { sensitivity and specificity }(85 \%) \text {. }\end{array}$ \\
\hline $\begin{array}{l}\text { Duong et al. } \\
(2007)[45]\end{array}$ & $\begin{array}{l}\text { AC: } 25 / 46 \\
\text { SCC: } 21 / 46\end{array}$ & CRT & 46 & cDNA microarrays & $\begin{array}{l}\text { Pretreatment } \\
\text { biopsy }\end{array}$ & $\begin{array}{l}\text { A } 32 \text {-gene classifier was produced in which } \\
10 \text { of } 21<\text { pCRs could be accurately } \\
\text { identified for ESCC }\end{array}$ \\
\hline $\begin{array}{l}\text { Maher et al. } \\
(2009) \text { [49] }\end{array}$ & $\begin{array}{l}\text { EC } \\
\text { training cohort: } 13 \\
\text { validation cohort }: 27\end{array}$ & CRT & 40 & $\begin{array}{l}\text { genome expression microarrays } \\
\text { and qRT-PCR }\end{array}$ & $\begin{array}{l}\text { Pretreatment } \\
\text { biopsy }\end{array}$ & $\begin{array}{l}\text { Five-genes based model predicted the re- } \\
\text { sponse with } 95 \% \text { accuracy in the validation } \\
\text { cohort }\end{array}$ \\
\hline $\begin{array}{l}\text { Wen et al. (2014) } \\
\text { [50] }\end{array}$ & $\begin{array}{l}\text { ESCC } \\
\text { training cohort: } 28 \\
\text { validation cohort }: 32\end{array}$ & CRT & 60 & $\begin{array}{l}\text { genome expression microarrays } \\
\text { and qRT-PCR }\end{array}$ & $\begin{array}{l}\text { Pretreatment } \\
\text { biopsy }\end{array}$ & $\begin{array}{l}\text { Three-genes(MMP,LIMCH1,Clorf } 226) \text { based } \\
\text { model predicted the response with } 81 \% \\
\text { accuracy in the validation cohort }\end{array}$ \\
\hline $\begin{array}{l}\text { Schauer et al. } \\
\text { (2010) [47] }\end{array}$ & EAC:47 & Chemotherapy & 47 & $\begin{array}{l}\text { genome expression microarrays } \\
\text { and IHC }\end{array}$ & $\begin{array}{l}\text { Pretreatment } \\
\text { biopsy }\end{array}$ & $\begin{array}{l}\text { Ephrin B3 receptor correlated with high } \\
\text { response rate }\end{array}$ \\
\hline
\end{tabular}

Abbreviations: PREP: TP53 apoptosis effector; S100A2: S100 calcium binding proteins; SPRR3: small proline-rich protein 3; MMP: matrix metalloproteinase; other abbreviations as in table 1.

In conclusion, conventional FDG-PET image-derived parameters, especially the relative changes of SUV values, have been proven a significant predictor of treatment response. Furthermore, spatial-temporal FDG-PET offers more information about the intensity, texture, geometry, and geometry-intensity features compared with the conventional PET measures with SUVs and will be useful for differentiating the responders to neoadjuvant CRT. Nevertheless, there are significant issues to be resolved with regard to the standardization of PET imaging protocols, image-processing methods and the time point for repeat imaging.

Diffusion-weighted magnetic resonance imaging (DWMRI) is also a functional imaging that is based on the microscopic random translational motion of water molecules in biological tissues. The magnitude of this motion is characterized by its apparent diffusion coefficient (ADC) values. Recently, a few studies have been published to evaluate the efficacy of ADC values in predicting neoadjuvant CRT response. Aoyagi et al. [66] analyzed the pretreatment ADC values of 80 patients with ESCC and found that an ADC value of $1.10 \times 10^{-3} \mathrm{~mm}^{2} / \mathrm{s}$ can differentiate CRT responders from non-responders (a high ADC group responded better to CRT than did a low ADC group) with a sensitivity, specificity, and accuracy of $73.8 \%, 86.8 \%$ and $80.0 \%$, respectively. Similarly, Imanishi et al. [67] reported that the ADC at the time of $20 \mathrm{~Gy}$ and the increased rate of the ADC at the time of $20 \mathrm{~Gy}$ were significant predictors of treatment response in locally advanced ESCC.

Computed tomography perfusion (CTP) images can quantify tumor vascularity by measuring the temporal changes in tissue attenuation following intravenous contrast administration, which has been reported to associate with tumor characterization, survival, and therapy response in EC [68-70]. The tumor blood flow was closely related to tissue oxygen status and tumor microcirculation, which was demonstrated to be an important factor for determining chemoradio-sensivity. Moreover, CT is the most common modality for evaluating cancer patients. Thus, CTP parameters will provide an important insight into the individualized treatment of EC.

\section{Conclusions}

Published data demonstrate that clinic-histopathological factors, molecular biomarkers, and functional imaging are predictive of neoadjuvant therapy. These clinical factors and biomarkers need to be further validated and novel biomarkers warrant additional exploration. FDG-PET image-derived parameters, especially the relative changes of SUV values, have been proven a significant predictor of treatment response. Nevertheless, there are significant issues to be resolved with regard to the standardization of PET imaging protocols, image-processing methods and the time point for repeat imaging. In addition, it is noteworthy that there is currently no comprehensive clinical study that incorporates clinical factors, biomarkers, and functional imaging to identify patients that may benefit from receiving neoadjuvant therapy. Therefore, a predictive model based on these factors needs to be established with a large, prospective, and homogeneous patient cohort in the near future. Standardization of staging, bi- 
omarker detection method, and image acquisition protocol will be critical for the generalization of this model. Aside from these outstanding discoveries, prospective, multi-center controlled trials, which stratify patients according to these predictive factors, will help guide individualized treatment strategies for patients with EC.

\section{Acknowledgements}

The Zhejiang Provincial Program for the Cultivation of High-level Innovative Health talents (to Yaping $\mathrm{Xu}$ )

\section{Competing Interests}

The authors have declared that no competing interest exists.

\section{References}

1. Jemal A, Bray F, Center MM, et al. Global cancer statistics. CA Cancer J Clin. 2011; 61:69-90.

2. Allum WH, Stenning SP, Bancewicz J et al. Long-term results of a randomized trial of surgery with or without preoperative chemotherapy in esophageal cancer. J Clin Oncol 2009; 27: 5062-67.

3. Ando $\mathrm{N}$, lizuka $\mathrm{T}$, Ide $\mathrm{H}$ et al. Surgery plus chemotherapy compared with surgery alone for localized squamous cell carcinoma of the thoracic esophagus: a Japan Clinical Oncology Group Study-JCOG9204. J Clin Oncol 2003; 21: 4592-96.

4. Ychou M, Boige V, Pignon J-P, et al. Perioperative chemotherapy compared with surgery alone for resectable gastroesophageal adenocarcinoma: an FNCLCC and FFCD multicenter phase III trial. J Clin Oncol. 2011; 29: 1715-21.

5. Sjoquist KM, Burmeister BH, Smithers BM, et al. Survival after neoadjuvant chemotherapy or chemoradiotherapy for resectable oesophageal carcinoma: an updated meta-analysis. Lancet Oncol. 2011; 12:681-92.

6. Matsuyama J, Doki Y, Yasuda T, et al.The effect of neoadjuvant chemotherapy on lymph node micrometastases in squamous cell carcinomas of the thoracic esophagus. Surgery. 141: 570-580, 2007.

7. Stahl M, Lehmann N, Walz MK, et al. Prediction of prognosis after trimodal therapy in patients with locally advanced squamous cell carcinoma of the oesophagus. Eur J Cancer. 2012; 48:2977-82.

8. Stahl M, Stuschke M, Lehmann N, et al. Chemoradiation with and without surgery in patients with locally advanced squamous cell carcinoma of the esophagus. J Clin Oncol. 2005 ; 23:2310-7.

9. Bedenne L, Michel P, Bouché $\mathrm{O}$, et al. Chemoradiation followed by surgery compared with chemoradiation alone in squamous cancer of the esophagus: FFCD 9102. J Clin Oncol. 2007; 25:1160-8.

10. Szumilo J, Chibowski D, D browski A. Assessment of the predictive value of clinical and histopathological factors as well as the immunoexpression ofp53 and bcl-2 proteins in response to preoperative chemotherapy for esophageal squamous cell carcinoma. Dis esophagus. 2000;13:191-7.

11. Huang RW, Chao YK, Wen YW, et al. Predictors of pathological complete response to neoadjuvant chemoradiotherapy for esophageal squamous cellcarcinoma. World J Surg Oncol. 2014; 12:170.

12. Hamai Y, Hihara J, Taomoto J, et al. Hemoglobin level influences tumor response and survival after neoadjuvant chemoradiotherapy for esophageal squamous cell carcinoma. World J Surg. 2014;38:2046-51

13. Patel VR, Hofstetter WL, Correa AM, et al. Signet ring cells in esophageal adenocarcinoma predict poor response to preoperative chemoradiation. Ann Thorac Surg. 2014; 98:1064-71.

14. Schneider PM, Baldus SE, Metzger R, et al. Histomorphologic tumor regression and lymph node metastases determine prognosis following neoadjuvant radiochemotherapy for esophageal cancer: implications for response classification. Ann Surg. 2005; 242:684-92.

15. Ajani JA, Correa AM, Hofstetter W, et al. Clinical parameters model for predicting pathologic complete response following preoperative chemoradiation in patients with esophageal cancer. Ann Oncol. 2012;23:2638-42.

16. Fujiwara $\mathrm{H}$, Shiozaki A, Furutani A, et al. Time course of serum C-reactive protein levels during induction chemoradiotherapy and its correlation with treatment response and survival in patients with advanced esophageal squamous cell carcinoma. Mol Clin Oncol. 2013;1:558-564.

17. Warnecke-Eberz U, Metzger R, Miyazono F, et al. High specificity of quantitative excision repair cross-complementing 1 messenger RNA expression for prediction of minor histopathological response to neoadjuvant radiochemotherapy in esophageal cancer. Clin Cancer Res. 2004;10:3794-9.
18. Metzger R, Warnecke-Eberz U, Alakus H, et al. Neoadjuvant radiochemotherapy in adenocarcinoma of the esophagus: ERCC1 gene polymorphisms for prediction of response and prognosis. J Gastrointest Surg. 2012;16:26-34.

19. Höfler $\mathrm{H}$, Langer $\mathrm{R}, \mathrm{Ott} \mathrm{K}$, et al. Prediction of response to neoadjuvant chemotherapy in carcinomas of the upper gastrointestinal tract. Adv Exp Med Biol. 2006;587:115-20.

20. Warnecke-Eberz U, Metzger R, Bollschweiler E, et al. TaqMan low-density arrays and analysis by artificial neuronal networks predict response to neoadjuvant chemoradiation in esophageal cancer. Pharmacogenomics. 2010;11:55-64.

21. Theisen J, Danenberg K, Ott K, et al. Predictors of response and survival for neoadjuvant treated patients with esophageal adenocarcinoma. Dis Esophagus. 2008;21:601-6.

22. Brabender J, Metzger R, Vallböhmer D, et al. Roles of thymidylate synthase and dihydropyrimidine dehydrogenase expression in blood as predictors of response to multimodal therapy in esophageal cancer. Surgery. 2012;151:306-12.

23. Bhatti I, Lee A, Lund J, et al. mall RNA: a large contributor to carcinogenesis? J Gastrointest Surg. $2009 ; 13: 1379-88$.

24. Odenthal M, Bollschweiler E, Grimminger PP, et al. MicroRNA profiling in locally advanced esophageal cancer indicates a high potential of miR-192 in prediction of multimodality therapy response. Int J Cancer. 2013;133:2454-63.

25. Hamano R, Miyata H, Yamasaki M, et al. Overexpression of miR-200c induces chemoresistance in esophageal cancers mediated through activation of the Akt signaling pathway. Clin Cancer Res. 2011;17:3029-38.

26. Hong $L$, Han $Y$, Zhang $H$, et al. The prognostic and chemotherapeutic value of miR-296 in esophageal squamous cell carcinoma. Ann Surg. 2010; 251:1056-63.

27. Hummel R, Watson DI, Smith C, et al. Mir-148a improves response to chemotherapy in sensitive and resistant oesophageal adenocarcinoma and squamous cell carcinoma cells. J Gastrointest Surg. 2011; 15:429-38.

28. Qi P, Du X. The long non-coding RNAs, a new cancer diagnostic and therapeutic gold mine. Mod Pathol. 2013; 26:155-65.

29. Tong YS, Zhou XL, Wang XW, et al. Association of decreased expression of long non-coding RNA LOC285194 with chemoradiotherapy resistance and poor prognosis in esophageal squamous cell carcinoma. J Transl Med. 2014; 12:233.

30. Cheng JC, Graber MS, Hsu FM, et al. High Serum Levels of Vascular Endothelial Growth Factor-A and Transforming Growth Factor- $\beta 1$ Before Neoadjuvant Chemoradiotherapy Predict Poor Outcomes in Patients with Esophageal Squamous Cell Carcinoma Receiving Combined Modality Therapy. Ann Surg Oncol .2014; 21:2361-8.

31. Hickey K, Grehan D, Reid IM, et al. Expression of epidermal growth factor receptor and proliferating cell nuclear antigen predicts response of esophageal squamous cell carcinoma to chemoradiotherapy. Cancer. 1994; 74:1693-8.

32. Sarbia M, Stahl M, Fink U, et al. Expression of apoptosis-regulating proteins and outcome of esophageal cancer patients treated by combined therapy modalities. Clin Cancer Res. 1998; 4:2991-7.

33. Nakashima S, Natsugoe S, Matsumoto M, et al. Expression of p53 and p21 is useful for the prediction of preoperative chemotherapeutic effects in esophageal carcinoma. Anticancer Res. 2000; 20:1933-7.

34. Kitamura K, Saeki H, Kawaguchi H, et al. Immunohistochemical status of the p53 protein and Ki-67 antigen using biopsied specimens can predict a sensitivity to neoadjuvant therapy in patients with esophageal cancer. Hepatogastroenterology. 2000; 47:419-23.

35. Miyazono F, Metzger R, Warnecke-Eberz U, et al. Quantitative c-erbB-2 but not c-erbB-1 mRNA expression is a promising marker to predict minor histopathologic response to neoadjuvant radiochemotherapy in oesophageal cancer. Br J Cancer. 2004; 91:666-72

36. Izzo JG, Malhotra U, Wu TT, et al. Association of activated transcription factor nuclear factor kappab with chemoradiation resistance and poor outcome in esophageal carcinoma. J Clin Oncol. 2006; 24:748-54.

37. Nakanoko T, Saeki $\mathrm{H}$, Morita $\mathrm{M}$, et al. Rad51 expression is a useful predictive factor for the efficacy of neoadjuvant chemoradiotherapy in squamous cell carcinoma of the esophagus. Ann Surg Oncol. 2014; 21:597-604.

38. Zhou YL, Zhang WC, Chen $\mathrm{XB}$, et al. The association between polymorphism of transforming growth factor- $\beta 1$ and radiochemotherapy response and survival in esophageal squamous cell carcinoma patients. Zhonghua Yu Fang Yi Xue Za Zhi. 2011; 45:583-7.

39. Ajani JA, Wang X, Song S, et al. ALDH-1 expression levels predict response or resistance to preoperative chemoradiation in resectable esophageal cancer patients. Mol Oncol. 2014; 8:142-9.

40. Suzuki $Y$, Mimura $K$, Yoshimoto $Y$, et al. Immunogenic tumor cell death induced by chemoradiotherapy in patients with esophageal squamous cell carcinoma. Cancer Res. 2012; 72: 3967-76.

41. Makuuchi Y, Honda K, Osaka Y, et al. Soluble interleukin-6 receptor is a serum biomarker for the response of esophageal carcinoma to neoadjuvant chemoradiotherapy. Cancer Sci. 2013; 104:1045-51.

42. Ponder BA. Cancer genetics. Nature. 2001; 411:336-41.

43. Ramaswamy S, Golub TR. DNA microarrays in clinical oncology. J Clin Oncol. 2002; 20:1932-41

44. Luthra R, Wu TT, Luthra MG, et al. Gene expression profiling of localized esophageal carcinomas: association with pathologic response to preoperative chemoradiation. J Clin Oncol. 2006; 24:259-67. 
45. Duong C, Greenawalt DM, Kowalczyk A, et al. Pretreatment gene expression profiles can be used to predict response to neoadjuvant chemoradiotherapy in esophageal cancer. Ann Surg Oncol. 2007; 14:3602-9.

46. Motoori M, Takemasa I, Yamasaki M, et al. Prediction of the response to chemotherapy in advanced esophageal cancer by gene expression profiling of biopsy samples. Int J Oncol. 2010; 37:1113-20.

47. Schauer M, Janssen KP, Rimkus C, et al. Microarray-based response prediction in esophageal adenocarcinoma. Clin Cancer Res. 2010; 16:330-7.

48. Metzger R, Heukamp L, Drebber U, et al. CUL2 and STK11 as novel response-predictive genes for neoadjuvant radiochemotherapy in esophageal cancer. Pharmacogenomics. 2010; 11:1105-13.

49. Maher SG, Gillham CM, Duggan SP, et al. Gene expression analysis of diagnostic biopsies predicts pathological response to neoadjuvant chemoradiotherapy of esophageal cancer. Ann Surg. 2009; 250:729-37.

50. Wen J, Yang H, Liu MZ, et al. Gene expression analysis of pretreatment biopsies predicts the pathological response of esophageal squamous cell carcinomas to neo-chemoradiotherapy. Ann Oncol. 2014; 25:1769-74.

51. Laterza E, de Manzoni G, Guglielmi A, et al. Endoscopic ultrasonography in the staging of esophageal carcinoma after preoperative radiotherapy and chemotherapy. Ann Thorac Surg. 1999; 67:1466-9.

52. Jones DR, Parker LA Jr, Detterbeck FC, et al. Inadequacy of computed tomography in assessing patients with esophageal carcinoma after induction chemoradiotherapy. Cancer. 1999; 85:1026-32.

53. Kim MK, Ryu JS, Kim SB, et al. Value of complete metabolic response by 18 F-fluorodeoxyglucose-positron emission tomography in oesophageal cancer for prediction of pathologic response and survival after preoperative chemoradiotherapy. Eur J Cancer. 2007; 43: 1385-1391.

54. Kato H, Fukuchi M, Miyazaki T, et al. Prediction of response to definitive chemoradiotherapy in esophageal cancer using positron emission tomography. Anticancer Res. 2007; 27:2627-33.

55. Javeri $\mathrm{H}_{\text {, Xiao }} \mathrm{L}$ Rohren $\mathrm{E}$ et al Influence of the baseline 18F-fluoro-2-deoxy-D-glucose positron emission tomography results on survival and pathologic response in patients with gastroesophageal cancer undergoing chemoradiation. Cancer. 2009; 115:624-30.

56. Swisher SG, Erasmus J, Maish M, et al. 2-Fluoro-2-deoxy-D-glucose positron emission tomography imaging is predictive of pathologic response and survival after preoperative chemoradiation in patients with esophageal carcinoma. Cancer. 2004; 101:1776-85.

57. Greven KM, Williams DW 3rd, McGuirt WF, et al. Serial positron emission tomography scans following radiation therapy of patients with head and neck cancer. Head Neck. 2001; 23:942-6.

58. Wieder HA, Brücher BL, Zimmermann F, et al. Time course of tumor metabolic activity during chemoradiotherapy of esophageal squamous cell carcinoma and response to treatment. J Clin Oncol. 2004; 22:900-8.

59. Ma JB, Chen EC, Song YP, et al. Prognostic significance of 18F-fluorodeoxyglucose positron emission tomography (PET)-based parameters in neoadjuvant chemoradiation treatment of esophageal carcinoma. Asian Pac J Cancer Prev. 2013; 14:2477-81.

60. Brücher BL, Weber W, Bauer M, et al. Neoadjuvant therapy of esophageal squamous cell carcinoma: response evaluation by positron emission tomography. Ann Surg. 2001; 233:300-9.

61. Makino T, Miyata $\mathrm{H}$, Yamasaki $\mathrm{M}$, et al. Utility of response evaluation to neo-adjuvant chemotherapy by (18)F-fluorodeoxyglucose-positron emission tomography in locally advanced esophageal squamous cell carcinoma. Surgery. 2010; 148:908-18.

62. Hatt M, Visvikis D, Pradier O, et al. Baseline ${ }^{18} \mathrm{~F}$-FDG PET image-derived parameters for therapy response prediction in oesophageal cancer. Eur J Nucl Med Mol Imaging. 2011; 38:1595-606.

63. Blom RL, Steenbakkers IR, Lammering G, et al. PET/CT-based metabolic tumour volume for response prediction of neoadjuvant chemoradiotherapy in oesophageal carcinoma. Eur J Nucl Med Mol Imaging. 2013; 40:1500-6.

64. Tan S, Kligerman S, Chen W, et al. Spatial-temporal $\left[{ }^{8} \mathrm{~F}\right]$ FDG-PET features for predicting pathologic response of esophageal cancer to neoadjuvant chemoradiation therapy. Int J Radiat Oncol Biol Phys. 2013; 85:1375-82.

65. Zhang $\mathrm{H}$, Tan S, Chen W, et al. Modeling pathologic response of esophageal cancer to chemoradiation therapy using spatial-temporal 18F-FDG PET features, clinical parameters, and demographics. Int J Radiat Oncol Biol Phys. 2014; 88:195-203.

66. Aoyagi, Shuto K, Okazumi S, et al. Apparent diffusion coefficient values measured by diffusion-weighted imaging predict chemoradiotherapeutic effect for advanced esophageal cancer. Dig Surg. 2011; 28:252-7.

67. Imanishi $S$, Shuto $K$, Aoyagi $T$, et al. Diffusion-weighted magnetic resonance imaging for predicting and detecting the early response to chemoradiotherapy of advanced esophageal squamous cell carcinoma. Dig Surg. 2013; 30:240-8.

68. Song T, Shen YG, Jiao NN, et al. Esophageal squamous cell carcinoma: assessing tumor angiogenesis using multi-slice CT perfusion imaging. Dig Dis Sci. 2012; 57:2195-202.

69. Hayano K, Okazumi S, Shuto K, et al. Perfusion CT can predict the response to chemoradiation therapy and survival in esophageal squamous cell carcinoma: initial clinical results. Oncol Rep. 2007; 18:901-8.

70. Makari Y, Yasuda T, Doki Y, et al. Correlation between tumor blood flow assessed by perfusion CT and effect of neoadjuvant therapy in advanced esophageal cancers. J Surg Oncol. 2007; 96:220-9. 